\title{
OCCURRENCE OF PSEUDOMICRODOCHIUM SUTTONII IN BRAZIL
}

\author{
Amanda Torres Nunes*, Maria Auxiliadora de Q. Cavalcanti, Lusinete Aciole de Queiroz \\ Departamento de Micologia, Centro de Ciências Biológicas, Universidade Federal de Pernambuco, Recife, \\ Pernambuco, Brasil.
}

Submitted: July 15, 1998; Returned to authors for corrections: September 21, 1998; Approved: November 12, 1998

\section{SHORT COMMUNICATION}

\begin{abstract}
Pseudomicrodochium suttonii was isolated from the soil of Derby Square, a leisure area in Recife city, Pernambuco, Brazil. For the isolation, suspensions were made in distilled sterile water. According to the literature, this is probably the first occurrence reported in South America.
\end{abstract}

Key words: Taxonomy, Pseudomicrodochium suttonii, soil

The genus Pseudomicrodochium, class Hyphomycetes, was first described by Sutton (7). The type species is $P$. suttonii.

The taxon was isolated from Castanea sativa Mill. Gard. Later, new species were described, including $P$. fusarioides, $P$. lauri, $P$. candidum, $P$. cilindricum and P. aciculare (8).

This work describes the isolation of $P$. suttonii from the soil of Derby Square, Recife, Pernambuco, Brazil. Surface and depth soil samples were collected and pooled, in a total of six pools.

The isolation procedure was done according to the method of Warcup (9). Suspensions were prepared in distilled sterile water, containing chloramphenicol $(75 \mathrm{mg} / \mathrm{l})$ and cycloheximide $(50 \mathrm{mg} / \mathrm{l})$. Ten grams of each pool were weighed, diluted $1: 100$ and $0.1 \mathrm{ml}$ was plated on the surface of Mycozel agar (5), in triplicate. Plates were maintained at room temperature $\left(28^{\circ} \mathrm{C} \pm\right.$ $1^{\circ} \mathrm{C}$ ) for seven days.
For identification, the criteria of Ellis (2), Ellis (3), Sutton (6) and de Hoog and Guarro (4) were used. The main characteristics of this species areas follows. Growth on potato dextrose agar (PDA) at room temperature $\left(28^{\circ} \mathrm{C} \pm 1^{\circ} \mathrm{C}\right)$ is slow, reaching $2.9 \mathrm{~cm}$ in diameter after 15 days. The colonies present a fluffy aspect, regular edge and a pale brown color. The reverse is smooth and presents a dark color. Hyphae are $1.5-2 \mu \mathrm{m}$ wide, pigmented, branched and septate. Conidiophores are absent. Conidiogeneous cells are intercallary or lateral, often without basal septum, cylindrical, whith an indistinct collarette, frequently producing conidia in a sympodial order. Conidia are straight to falcate, acicular, pale brown, smoothwalled, 16-28 x 0.8-1.1 $\mu \mathrm{m}, 3-6$ septate (Fig. 1).

This Hyphomycetes species, P. suttonii, is a species of rare incidence, and this is probably the first citation in Brazil. Other authors have reported the isolation of P. suttonii from animal phaeohyphomycosis (1).

\footnotetext{
* Corresponding author. Mailling address: Universidade Federal de Pernambuco, UFPE, Centro de Ciências Biológicas, Departamento de Micologia, CEP 50670-420, Recife, Pernambuco, Brasil. Fax: (+5581) 271-8482
} 
This strain is stored in the culture collection of the Federal University of Pernambuco, Biological Sciences Center, Department of Mycology (Micoteca URM), with register number 4006.

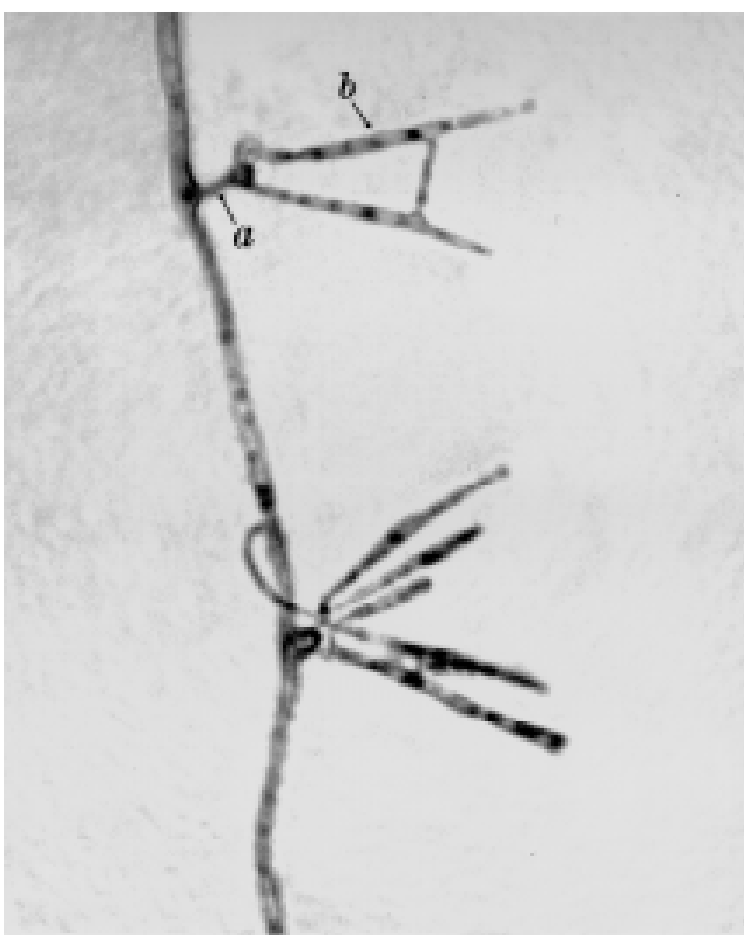

Figure 1- Pseudomicrodochium suttonii. Conidiogenous cells (a), conidia (b). (scale - 100X)
RESUMO

\section{Ocorrência de Pseudomicrodochium suttoni no Brasil}

Pseudomicrodochium suttonii foi isolado do solo da Praça do Derby, uma área de lazer da cidade do Recife, Pernambuco, Brasil. Para o isolamento, foram feitas suspensões utilizando-se água destilada e esterilizada. De acordo com literatura consultada, provavelmente esta é a primeira ocorrência notificada na América do Sul.

Palavras-chave: Taxonomia, Pseudomicrodochium suttonii, solo

\section{REFERENCES}

1. Ajello, L.; Padhye, A.A.; Payne, M. Phaeohyphomycosis in a dog caused by Pseudomicrodochium suttonii sp. nov. Mycotaxon, 12: 131-6, 1980.

2. 2.Ellis, M.B. Dematiaceous Hyphomycetes. Commonwealth Mycological Institute Kew, Surrey, England, 1971, 608p.

3. 3.Ellis, M.B. More Dematiaceous Hyphomycetes. Commonwealth Mycological Institute Kew, Surrey, England, 1976, 507p.

4. de Hoog, G.S.; Guarro, J. Atlas of Clinical Fungi. CBS, Netherlands, 1995, 719p.

5. Lacaz, C. da S.; Porto, E.; Martins, J.E.C. Micologia Médica: fungos, actinomycetes e algas de interesse médico. $8^{\mathrm{a}}$ ed., São Paulo: Savier EDUSP, 1991, 695p.

6. Sutton, B.C. The Coelomycetes. Commonwealth Mycological Institute, Kew Surrey, England, 1980, 696p.

7. Sutton, B.C. Hyphomycetes on cupules of Castanea sativa. Trans. Br. mycol. Soc., 64: 405-26, 1975.

8. Sutton, B.C.; Campbell, C.K.; Goldschmied-Reouven, A. Pseudomicrodochium fusarioides sp. nov., isolated from human bronchial fluid. Mycopathologia, 114: 159-161, 1991.

9. Warcup, J.H. The soil plate method for isolation of fungi from soil. Nature, London, 166:117-118, 1950. 